\title{
Endemic plants of tropical dry evergreen forest, Southern India
}

\section{Natesan Balachandran ${ }^{1 *}$, Krishnamurthy Rajendiran ${ }^{2} \&$ Walter Gastmans ${ }^{3}$}

${ }^{1}$ Ecology Department, French Institute of Pondicherry, Puducherry - 605 001, India

${ }^{2}$ Department of Botany, Bharathidasan Govt College for Women, Puducherry - 605003, India

${ }^{3}$ Auro Herbarium, Shakti, Auroville - 605 101, Villupuram District, India

* corresponding author (e-mail: balachandran.n@ifpindia.org)

\begin{abstract}
During the last two decades of intensive botanical survey of the tropical dry evergreen forest, a total of 82 endemic taxa were found out of 1142 species enumerated from 85 sites in the three Coromandel Coastal districts of the state Tamil Nadu: Cuddalore, Kancheepurm and Villupuram, and in the Pondicherry district. Of 82 species, 17 are trees, 11 shrubs, 9 climbers and 45 herbs. Distribution of these endemic species was analyzed and categorised as endemic to the country, peninsular India, southern India, Eastern and Western Ghats, and at the state and district level. Interestingly, the study found that some endemic species were disjunctly distributed between districts, states, ghats, climatic regimes and bioregions. Anthropogenic disturbance and species threat status were also studied and discussed.
\end{abstract}

Key words: Coromandel Coast, endemics, disjunct distribution, Pondicherry, Tamil Nadu, threat status, tropical dry evergreen forest

\section{Introduction}

India is one of 18 extremely diverse and top 10 species-rich countries of the world. Out of 18043 species, a total of 4381 taxa belonging to 1007 genera and 176 families, including 4303 angiosperms, 12 gymnosperms and 66 pteridophytes, have been confirmed as endemic to India (Singh \& Dash 2014). Recently, among angiosperms, a total of 58 genera have been identified as endemic to India (Singh et al. 2015). Chatterjee (1939, 1962) was the first researcher who studied the endemism of the Indian flora and evaluated that 6850 species are unique to this region ( $61 \%$ of flowering plants), of which 3169 species are restricted to the Himalayas and 2045 to Peninsular India (PI). Blasco (1971) estimated that there are about 1268 dicotyledons endemic to South India; however, Nayar (1977) recorded 2100 flowering plants endemic to PI. Later, Nayar (1980a) reported 141 genera endemic to India; while Ahmedullah \& Nayar (1986) found 55 genera endemic to PI of which 45 are monotypic (Nayar 1980a). Recently, Irwin \& Narasimhan (2011) enumerated only 49 genera that are endemic to India, excluding several genera based on nomenclatural changes and extended distribution. Nayar (1980b) categorised the endemic genera of India into 3 patterns based on the distribution, i.e., Himalayan endemic genera, Peninsular Indian endemic genera and Andaman \& Nicobar Islands endemic genera.

In India, the Western Ghats (WG) has much more endemic taxa (2116 species) than the rest of India. In the state-wise analysis, Tamil Nadu ranks first with 410 species, followed by Kerala (357), and Maharashtra (278), while Andaman and Nicobar Islands together contribute 278 taxa (Singh et al. 2015).

A total of 166 endemic taxa, representing 117 genera and 43 families, are known to occur in the Eastern Ghats (EG), of which 129 are dicots and 46 monocots. Sudhakar Reddy \& Raju (2008) recorded 400 endemic spermatophytes from the EGs of Andhra Pradesh and their adjacent coastal plains. The Flora of Tamil Nadu was published in 1983, 1987 and 1989 in 3 volumes, afterwards, Betty \& Ramachandran (2014) added 192 taxa belonging to 130 genera and 61 families between the period of 1989 and 2013 based on published sources, unpublished thesis and research reports made by several botanists (Matthew 1999; Uma Maheshwari \& Daniel 
2001; Ramachandran et al. 2006; Manickam et al. 2008; Viswanathan \& Manikandan 2008; Kabeer \& Nair 2009; Yarrayya et al. 2015). Out of them, 87 taxa are new to science, as well as endemic to the state of Tamil Nadu. High concentration of endemic plants directly reflects the habitat stability, environmental quality, rich biodiversity and conservation values in a specific area. The main aim of this work is to explore the wealth of endemic plants diversity from the fragile tropical dry evergreen forests and to know the current threat status of these plant species.

\section{Material and methods}

The natural vegetation occurring along the east coast of Southern India, extending from Visakhapattinam in Andhra Pradesh in the North to Ramanathapuram in Tamil Nadu in the South, was described as tropical dry evergreen forest (TDEF) (Champion \& Seth 1968). These forest types are found in 13 coastal districts out of 32 districts in Tamil Nadu. The state lies between $8^{\circ} 5^{\prime}$ to $13^{\circ} 35^{\prime} \mathrm{N}$ latitude and $76^{\circ} 15^{\prime}$ to $80^{\circ} 20^{\prime} \mathrm{E}$ longitude and is situated on the south eastern side of Indian

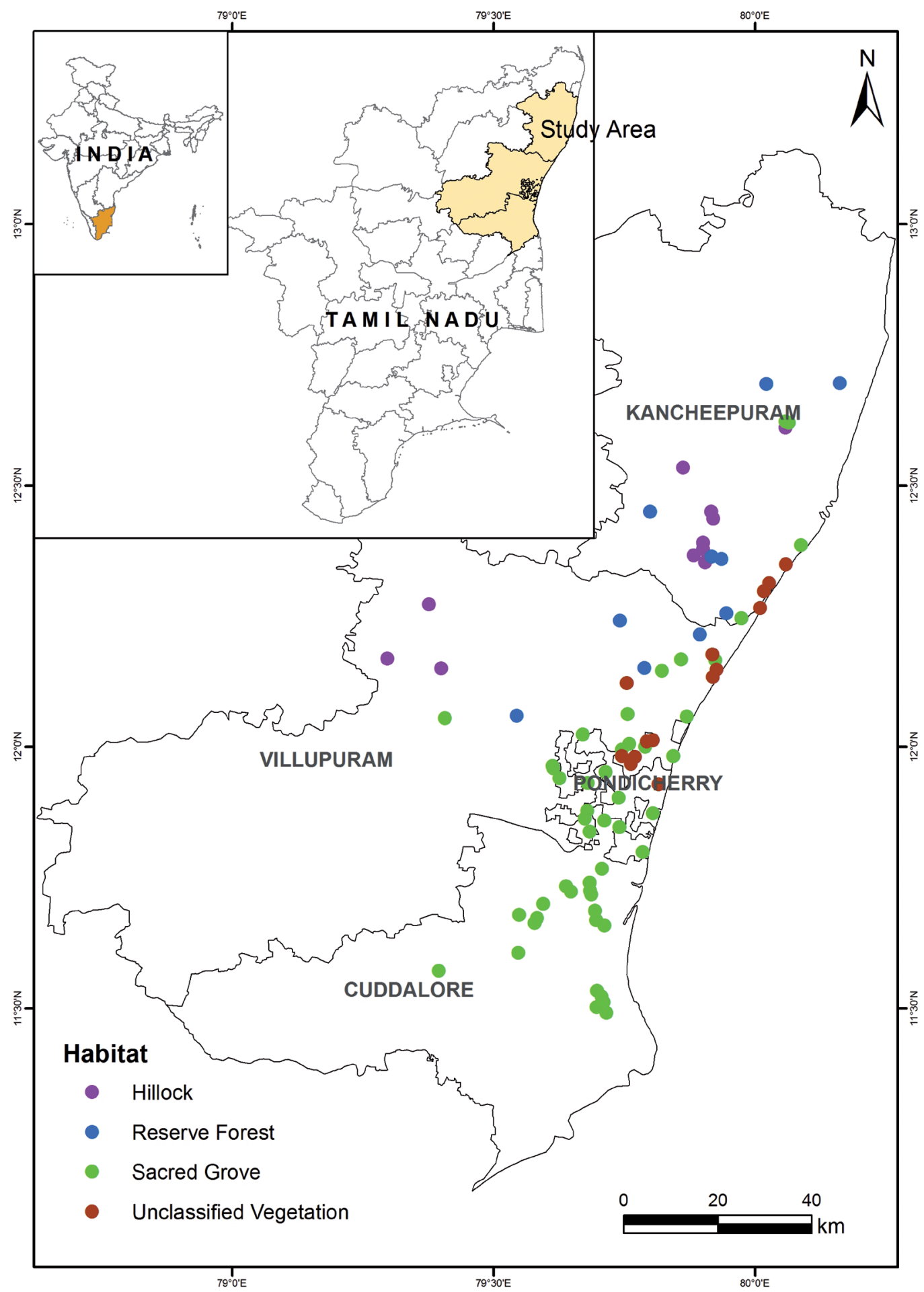

Fig. 1. Study area map 
Peninsula. It has a coast line of $990 \mathrm{~km}$ in the east and a land boundary of $1200 \mathrm{~km}$ in the west.

\subsection{Study area}

Four districts were selected in the present study, including three Coromandel Coastal districts of Southern India, i.e., Kancheepuram, Villupuram and Cuddalore from the state Tamil Nadu, and the fourth district was Pondicherry (Fig. 1). In Cuddalore, forest cover is $444 \mathrm{~km}^{2}(11.98 \%)$ out of $3706 \mathrm{~km}^{2}$, in Kancheepuram $372 \mathrm{~km}^{2}(8.31 \%)$ out of $4474 \mathrm{~km}^{2}$ and in Villupuram $1011 \mathrm{~km}^{2}(14.06 \%)$ out of $7190 \mathrm{~km}^{2}$ of geographical area (Annamalai 2004). The forest cover at the Union Territory of Pondicherry is $50.06 \mathrm{~km}^{2}(10.43 \%)$ out of $480 \mathrm{~km}^{2}$ of area (Forest Survey of India, 2013).

Geologically, part of Cuddalore and Villupuram districts belonged to the formation of Cuddalore sandstone during Miocene period (Meher-Homji 1970). The soil along the coast is sandy loam or red ferralitic and in certain places covered with alluvial deposits and becoming clayey beneath (Meher-Homji 1974, 1984). The coastal plains are extending up to 40-60 km (Mani 1974) and are overlained by a thin soil layer supporting agriculture. The substratum erupted into hillocks and mounds in the Kancheepuram and Villupuram districts and into undulating terrain in the Cuddalore district. The scattered hillocks rise up to $450 \mathrm{~m}$ with interrupted vegetation among the charkonite or gneiss rocks. The natural vegetation is mostly found on less fertile and red ferralitic soil, whereas black clay and alluvial soils were brought under cultivation (Marlange \& Meher-Homji 1965).

A typical maritime tropical climate with dissymmetric rainfall regime occurs in the study area. The mean annual rainfall recorded during 2007-2016 period was $1256 \mathrm{~mm}$, with mean rainy days of 56 per year. The minimum temperature of $17.7^{\circ} \mathrm{C}$ is in January, maximum temperature of $40.5^{\circ} \mathrm{C}$ in May, and the mean is $28.5^{\circ} \mathrm{C}$. The average relative humidity is $76 \%$ and the weather is generally cool during December to January with the late nights dewy. Dry weather prevails during April to June. Wind speed ranges from $5-9 \mathrm{~km} / \mathrm{h}$ during July to September, but it is extremely higher during the cyclonic days, during October to December.

\subsection{Field survey}

Four types of vegetation cover, including micro- and macro- habitats, i.e., Hillocks (HL), Reserve Forest (RF), Sacred Groves (SG) and Unclassified Vegetation (UC), were identified using Geological Survey of India (GSI) map, Google map and interview with people. The areas of HL vegetation are ranging from 680 to 2200 , RFs from 100 to 350, SGs from one to 40 and UCs from 0.5 to 35 hectares (ha). The elevation of HL was found between 150 and 450, RFs 100 to 350, SGs sea level to 80 and UC sea level to $40 \mathrm{~m}$ a.s.1.
Eighty five sites were selected in four districts and botanical surveys were made extensively once a week by a team of four members, visiting each and every site within an interval of 4-6 months. Pre-monsoon and post-monsoon changes were monitored from 1996 to 2016. These sites were geo-referenced with Garmin Global Positioning System (GPS), followed by intensive species inventory, including herbs, shrubs, trees and climbers; collection of voucher samples and photographic documentation of the key characters of the plants. A total of 12816 herbarium sheets were prepared from the sample collections and deposited at the AURO Herbarium, Auroville, India. The nomenclature of all plant species recorded in this study were verified with the site 'The Plant List' (http://www.theplantlist.org/).

\subsection{Analyses}

Phyto-geographical distribution of endemics was studied, with six areas of endemism categorised into endemic to: (1) the state Tamil Nadu, (2) Eastern Ghats (EG), (3) EG \& Western Ghats (WG), (4) Southern India (SI), (5) Peninsular India (PI) and (6) Entire India except Himalayas. In addition, disjunct nature of distribution of these endemic species between or among the areas was also studied. Site disturbances such as: browsing, cutting, lopping, and clear felling, encroachment for cultivation purposes, construction of a big modern temple, construction and widening of the metal road, digging irrigation channels and cementing the thrashing floor, were studied and categorised into low, medium and high, following Venkateswaran \& Parthasarathy (2003). High ranks signify high levels of anthropogenic disturbance in the forests. The disturbance levels were correlated with four growth forms, threat status of species and their values.

\section{Results}

Among the 85 sites studied, 25 (SG) sites are from Cuddalore, 22 ( 8 HL, 6 RF, 4 SG, 4 UC) from Kancheepuram and 28 (3 HL, 4 RF, 13 SG, 8 UC) from Villupuram districts of Tamil Nadu, while 10 (8 SG, 2 UC) from Pondicherry. Altogether, 1,142 species from 125 families and 580 genera were listed, of which 191 species are trees, 105 shrubs, 161 climbers and 685 herbs. Analysis of the results showed that among trees the dominant family was Leguminosae (34 species), among shrubs Rubiaceae (12 species), for climbers Convolvulaceae (27 species) and for herbs Poaceae (132 species). Ficus (13) is the dominant genus among trees; among shrubs dominated five genera, i.e., Capparis, Grewia, Jatropha, Polyalthia and Premna, with 3 species each; Ipomoea (13) is the dominant genus of climbers and Cyperus (26) among herbs. 


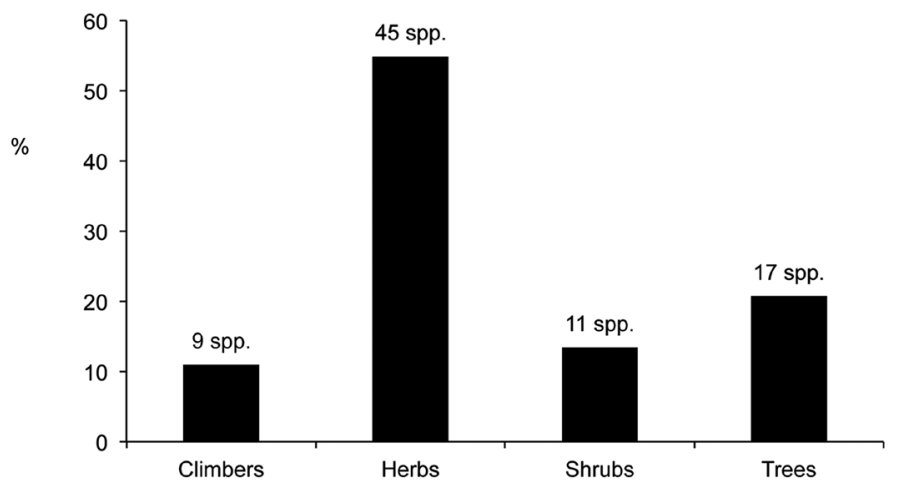

Fig. 2. The number of endemic plant species found in the studied tropical dry evergreen forest of the Coromandel Coast of Peninsular India according to different growth forms

In the presented work, we found $82(7.18 \%)$ endemic species from the TDEF that were distributed along the Coromandel Coast of Peninsular India, of which 17 species were trees, 11 shrubs, 9 climbers and 45 herbs
(Appendix 1; Fig. 2). These endemic species were represented by 65 genera and 31 families, of which Leguminosae (10 species from 7 genera) was the dominant family, followed by Acanthaceae $(9$ species from

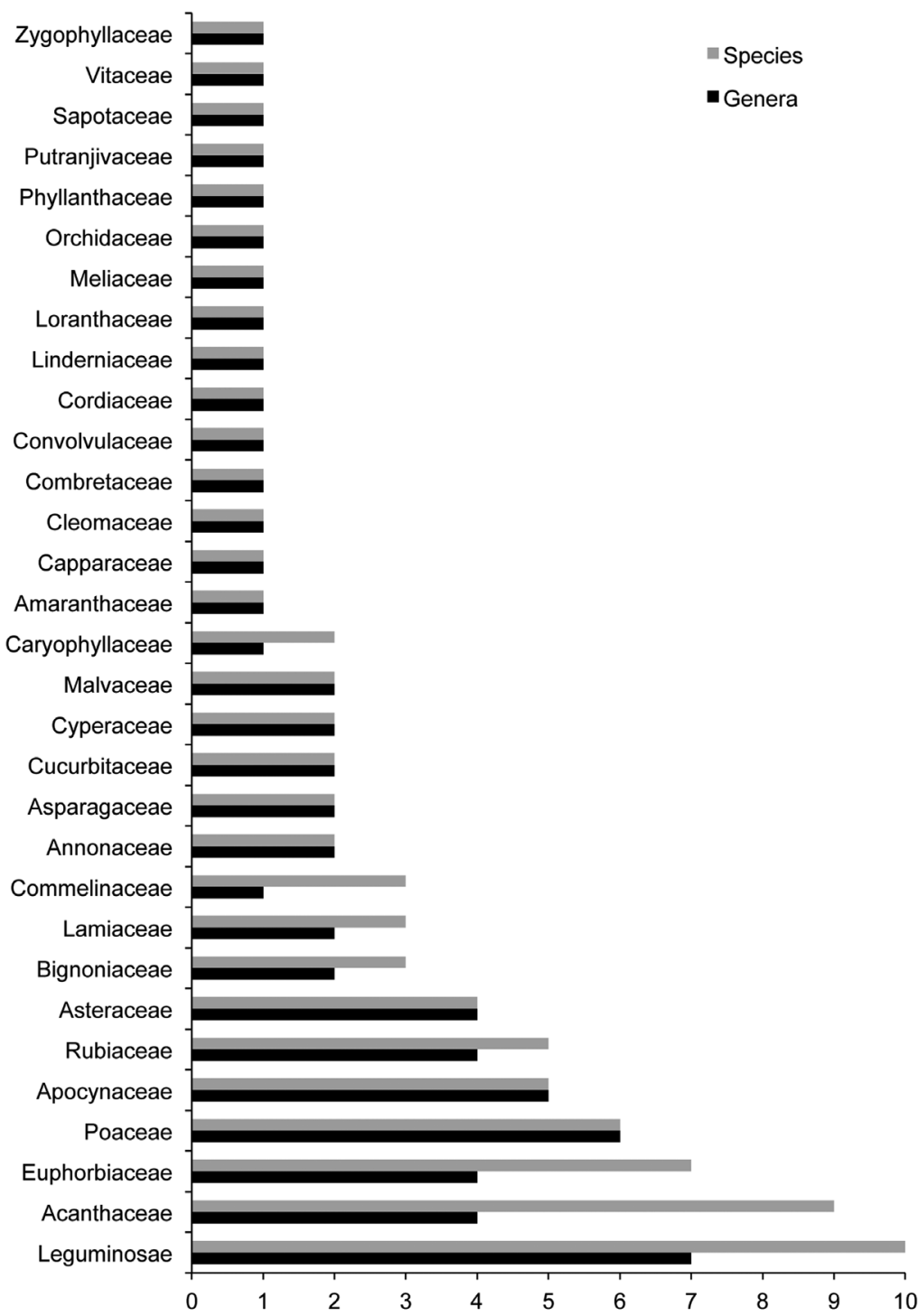

Fig. 3. Distribution of endemic plant species and genera of the studied tropical dry evergreen forest of the Coromandel Coast of Peninsular India within families 
Table 1. The number of endemic plant species of the studied tropical dry evergreen forest of the Coromandel Coast of Peninsular India found in the habitats of different level of disturbance, according to plant growth forms, threat status and medicinal and economic values

\begin{tabular}{llccccc}
\hline \multirow{2}{*}{ Endemic species characteristics } & \multirow{2}{*}{$\begin{array}{c}\text { Total number } \\
\text { of species }\end{array}$} & $\begin{array}{c}\text { Undisturbed } \\
\text { habitats }\end{array}$ & \multicolumn{3}{c}{ Disturbed habitats } \\
\cline { 5 - 7 } Growth form & Herbs & 45 & 11 & Low & Medium & High \\
\cline { 5 - 7 } & Shrubs & 11 & 3 & 6 & 20 & 5 \\
& Trees & 17 & 6 & 2 & 4 & 5 \\
& Climbers & 9 & 4 & 1 & 3 & 1 \\
Threat status & IUCN category & 6 & 3 & 0 & 2 & 1 \\
& Based on published resources & 10 & 3 & 3 & 3 & 1 \\
\multirow{5}{*}{ Values } & Not evaluated & 66 & 18 & 15 & 23 & 10 \\
& Medicinal \& economic & 41 & 10 & 8 & 14 & 9 \\
& None & 41 & 14 & 10 & 14 & 3 \\
\hline
\end{tabular}

4 genera), Euphorbiaceae (7 species from 4 genera) and Poaceae (6 from 6 genera). The other dominant families were Apocynaceae, Rubiaceae and Asteraceae (Fig. 3).

\subsection{Habitats}

Four levels of disturbance of habitats were determined in the studied area based on qualitative assessment - undisturbed, low, medium and high (Table 1). These levels were correlated with the number of endemic species representing different growth forms, threat status and ethno-botanical values. In general, from 50 to $65 \%$ of species were represented in the disturbed category. Maximum number of species was found for the medium level of disturbance, followed by undisturbed, low and high level of disturbance.

\subsection{Distribution}

Based on geographical distribution, the endemic species from TDEF were divided into six groups. Among them, Deccania pubescens var. candolleana, Pterocarpus santalinus and Sterculia populifolia were spotted only in EG of Andhra Pradesh and Tamil Nadu. Four species i.e., Derris ovalifolia, Mallotus resinosus var. muricatus, Mussaenda glabrata and Rhynchosia courtallensis were found both in EG and WG (Appendix 2). Twenty four species were distributed across the four southern states of India and another 24 species in PI. Three species, i.e., Crotalaria pusilla, Dolichandrone falcata and Hardwickia binata, were found across the country, except Himalayas (Appendix 3). The remaining 15 species were distributed unregularly without any regional limitations.

\subsection{Narrow endemics}

Nine species, such as: Carissa salicina, Cordia ramanujamii, Derris ovalifolia, Dipcadi montanum var. madrasicum, Drypetes porteri, Huberantha senjiana, Lindernia minima, Mussaenda tomentosa and
Tetrastigma tamilnadense, were endemic to the state Tamil Nadu, while $C$. ramanujamii, $H$. senjiana and $T$. tamilnadense are neo-endemic. The first two neoendemic species are restricted to the area of $50 \mathrm{~km}^{2}$ of Gingee hills. D. porteri and M. tomentosa were disjunctly distributed between Tirunelveli and Gingee hills (Appendix 4).

\subsection{Species with disjunct distribution}

Thirteen species, i.e.: Carissa salicina, Crotalaria willdenowiana, Derris ovalifolia, Dipcadi montaum var. madrasicum, Drypetes porteri, Justicia beddomei, Lindernia minima, Mallotus resinosus var. muricatus, Melothria angulata, Mussaenda glabrata, M. tomentosa, Polycarpaea corymbosa var. longipetala, and Rhynchosia courtallensis, have very scattered distribution between EG and WG of Tamil Nadu, while $M$. glabrata showed extended distribution from WG to EG. The distribution is disjunct for: Discospermum sphaerocarpum and Cyanotis papilionacea between Tamil Nadu and Maharashtra, Garnotia elata and Glossocardia bosvallia between SI and Uttar Pradesh, Indigofera mysorensis between SI and West Bengal, Leucas diffusa between SI and Delhi, L. wightiana between SI and Gujarat, Manisuris myurus between SI \& Manipur, Oldenlandia attenuata between EG and Uttar Pradesh, Senna montana between SI and Gujarat and Tricholepis radicans between SI and Rajasthan (Appendix 4). The remaining 24 species were very scattered within SI.

\subsection{Doubtful endemics}

Two species, i.e., Sehima sulcatum and Zenkeria elegans of Poaceae are considered as doubtful endemics because Singh et al. (2015), Krishnamurthy et al. (2014), Henry et al. (1989) and Ahmedullah \& Nayar (1986) treated them as endemic, whereas Kabeer \& Nair (2009) determined as non-endemic. Meanwhile, Krishnamurthy et al. (2014) included the later species on the 'endangered' species list. 


\subsection{Threat status}

According to IUCN (2017), a total of 66 (80.48 \%) out of 82 endemic species were listed as 'not evaluated' and their population status in the wild habitats is also unknown. So far, only six species, i.e., Aglaia elaeagnoidea (LC, Pannell 1998), Decalepis hamiltonii (ENA2cd, Ved et al. 2015), Drypetes porteri (EN-B1+2c, WCMC 1998), Lindernia minima (EN-B1ab+2ab, Rehel 2011), Pterocarpus santalinus (EN-B1+2de, CAMP 1998), and Sterculia populifolia (CR, WCMC 1998, Rao et al. 2011) are assessed according to IUCN criteria. Based on the published resources, 10 species, such as: Chrysopogon verticillatus (Kabeer \& Nair 2009), Crotalaria willdenowiana (Krishnamurthy et al. 2014), Derris ovalifolia (Thothathri 1982; Balachandran \& Rajendiran 2014; Krishnamurthy et al. 2014), Dipcadi montanum var. madrasicum (Ahmedullah \& Nayar 1986; Prabhu Kumar et al. 2013), Discospermum sphaerocarpum (Henry et al. 1987), Justicia beddomei (Ahmedullah \& Nayar 1986), Leucas wightiana (Ahmedullah \& Nayar 1986), Melothria angulata (Nair \& Henry 1983), Rhynchosia courtallensis (Krishnamurthy et al. 2014) and Sarcostemma intermedium (Krishnamurthy et al. 2014), are known as rare or endangered or threatened.

\section{Discussion}

The dominant families, i.e., Leguminosae (10 spp.), Acanthaceae (9), Euphorbiaceae (7), Poaceae (6), Apocynaceae (5) and Rubiaceae (5) determined in the present study coincide with local (Ramanujam et al. 2007), regional (Nayar 1996) and national (Singh \& Dash 2014; Singh et al. 2015) analyses. Compared to the reports of Meher-Homji (1974), Balasubramanian (1987), Ramanujam \& Kadamban (1999), Parthasarathy et al. (2008), Praveen Kumar (2011) and Balachandran (2016), in this study, 9 out of 82 endemic species are restricted to the state Tamil Nadu, 3 to EG, 4 to EG \& WG, 24 to SI, 24 to PI, 3 to entire India and 15 elsewhere. These data show the richness of plant diversity and the abundance of endemics found in TDEF.

The International Union for Conservation of Nature and Natural Resources (Walter \& Gillett 1998) assessed the global threat status of 33,418 species of Angiosperms, of which 1,215 species are reported from India, with 690 (55.8\%) species evaluated as Indeterminate (I). In this study, $80 \%$ of endemic species were in 'not evaluated' category. According to Isik (2011), three-quarters of narrow endemic species of plants and animals are known to become extinct due to habitat loss or fragmentation. Thus, Nair (1991) statement: "it is very essential that rare, threatened and presumed extinct taxa should be repeatedly searched for in their type localities", should be strictly followed and population status assessment for such species should be conducted repetitively.

Majority of endemic species populations are isolated due to geographical, ecological, edaphic and climatic barriers and such fragmented patches of vegetation were more pronounced in EG, which is important from the viewpoint of conservation (Nayar et al. 1984; Gopalan \& Henry 2000). This situation is more favourable to the narrow endemic species, like: Cordia ramanujamii, Huberantha senjiana and Mussaenda tomentosa in the Pakkam Malai reserve forest, Gingee hills of EG (Balachandran 2016).The other disjunctly distributed species, like: Blumea eriantha, Cyanotis tuberosa, Drypetes porteri, Derris ovalifolia, Discospermum sphaerocarpum, Indigofera mysorensis, Leucas wightiana, Manisuris myuros, and Melothria angulata, distributed between the two Ghats/bioregions have to be considered as crucial for conservation management.

It was estimated that $2-25 \%$ of plant species will become extinct or threatened with extinction in tropical forest in the nearest future (UNEP 1995). It is also estimated that $22-47 \%$ of species might have already become threatened with extinction (Pitman \& Jørgensen 2002). In India, TDEF occupies about $2,482.52 \mathrm{~km}^{2}$ ( $1.61 \%$ of the country territory), of which only $41.08 \mathrm{~km}^{2}(0.1 \%)$ occurs in Tamil Nadu (Areendran \& Rao 2006). According to Krishnamurthy et al. (2014), the TDEF found along the Coromandel Coast is an 'endangered forest' type. In this paradigm, Jain \& Rao (1983) statement "if endemic species are eliminated from our country it will mean that they will be annihilated from the whole world, will be loss to science, will be struck off the roles of biological resources of this earth" should be profoundly considered. Thus, a highly fragmented form of TDEF ecosystem, indeterminate IUCN status of narrow endemics and their disjunct distribution within different bioregions of India should be considered a high priority indication for the vegetation assessment at regular intervals and conservation programs.

Acknowledgements: The authors are thankful to Prof. Frederic Landy, Director and Dr. Raphael Mathevet, Head of Ecology, French Institute of Pondicherry for their constant support and encouragement; financial support for the survey from 1994 to 2000 by Danish, 2001-04 by European Commission, 2005-10 by Auroville Coastal Development Centre; Head of Forest Force and Districts Forest Officers of Forest and Wild Life, Tamil Nadu granted permission to do the botanical survey in RFs; Mr. Paul Blanchflower and Mr. Jaap dan Hollander accompanied all the times during the survey and provided photos of some species. 


\section{References}

Ahmedullah M. \& Nayar M. P. 1986. Endemic Plants of Indian region. Vol. 1 (Peninsular India). Botanical Survey of India, Calcutta.

Annamalai R. 2004. Tamil Nadu Biodiversity Strategy Action Plan. 143 pp. Tamil Nadu Forest Department, Government of Tamil Nadu, Chennai.

Areendran G. \& Rao P. 2006. Vegetation types of the southern Eastern Ghats - A Remote Sensing Perspective. WWF India, New Delhi, India.

Balachandran N. 2016. Perspectives of Plant Diversity in Tropical Dry Evergreen Forest along the Coromandel coast of Tamil Nadu and Pondicherry. PhD Thesis, Pondicherry University.

BalachandRAN N. \& RajendiRAn K. 2014. Disjunct distribution of five endemic plants from the tropical dry evergreen forest of Tamil Nadu, India. Ind J Plant Sci 4(3): 15-21.

Balasubramanian K. 1987. Biotaxonomical studies of Marakkanam RF, Coromandel coast. PhD Thesis. Annamalai University.

Betty T. \& RamachandRan V. S. 2014. Additions to the Flora of Tamil Nadu. J. Biod., Photon 113: 355-359.

Blasco F. 1971. Montagnes du sud deI'nde: forets, savanes, ecologie. Inst, Fr. Pondicherry, Trv, Sec. Sci. tech. Tome vol. X, 436 pp.

CAMP Workshops on Medicinal Plants, India (January 1997). 1998. Pterocarpus santalinus. The IUCN Red List of Threatened Species 1998: e.T32104A9679328. http://dx.doi.org/10.2305/IUCN.UK.1998.RLTS. T32104A9679328.en. Downloaded on 28 November 2016.

Champion H. G. \& Seth S. K. 1968. Revised survey of the forest types of India. Manager of Publications, New Delhi.

Chatterjee D. 1939 (1940). Studies on the endemic flora of India and Burma. J. Royal Asiatic Soc. Bengal. 5: $19-69$

ChatterJee D. 1962. Floristic pattern in Indian vegetation. Proc. Summer School Botany, Darjeeling, 32-42 pp. New Delhi.

Forest SuRvey of India. 2013. Forest Cover In: India State Forest Report 2013, FSI, Dehra Dun, 11-32. http:// fsi.nic.in/cover_2013/sfr_forest_cover.pdf accessed on 25 May $201 \overline{5}$.

Gopalan R. \& Henry A. N. 2000. Endemic Plants of India, Camp for the strict endemics of Agasthiyamalai hills, Southern Western Ghats. 476 pp. Bishen Singh Mahendra Pal Singh, Dehra Dun.

Henry A. N., Chithra V. \& Balakrishnan N. P. 1989. Flora of Tamil Nadu, India. Series 1: Analysis. Vol 3. Botanical Survey of India, Coimbatore.

Henry A.N., Kumari G. R. \& Chithra V. 1987. Flora of Tamil Nadu, India. Series 1: Analysis. Vol. 2, Botanical Survey of India, Coimbatore.

IRwin S. J. \& NARASIMHAN D. 2011. Endemic genera of Angiosperms in India: A Review. Rheedea 21: 87-105.

IsIK K. 2011. Rare and endemic species: why are they prone to extinction? Turk J Bot 35: 411-417.
IUCN 2017. The IUCN Red List of Threatened Species. Version 2017-3.1 http://www.iucnredlist.org/search downloaded on 28th June 2017

JAIN S. K. \& RAO R. R. 1983. An Assessment of the Threatened Plants of India. Botanical Survey of India. Kolkata.

Kabeer K. A. A. \& Nair V. J. 2009. Flora of Tamil Nadu - Grasses. 525 pp. Botanical Survey of India, Coimbatore.

Krishnamurthy K., Murugan R. \& Ravikumar K. 2014. Bioresources of the Eastern Ghats, Their Conservation and Management. 824 pp. Bishen Singh Mahendra Pal Singh, Dehra Dun.

MANI M. S. 1974. Ecology and Biogeography in India. BV Publishers, The Netherlands.

Manickam V. S., Murugan C., Sundaresan V. \& Jothi G. J. 2008. Flora of Tirunelveli Hills: southern Western Ghats. Bishen Singh Mahendra Pal Singh, Dehra Dun.

Marlange M. \& Meher-Homu V. M. 1965. Phytosociological studies in the Pondicherry Region. J. Indian Bot. Society 167-182.

Matthew K. M. 1999. Flora of the Palni Hills. Vol 1- III. The Rapinat Herbarium, Tiruchirapalli.

Meher-Homs V. M. 1970. Notes on some peculiar cases of Phytogeographic Distribution. J. Bombay Nat. Hist. Society 67: 81-87.

Meher-Homji V. M. 1974. On the origin of tropical dry evergreen forest of south India. Int. J. Eco. Environ. Science 1: 19-39.

Meher-Homji V. M. 1984. A New Classification of the Phytogeographic zones of India. Indian J. Botany 7: 224-233.

NAIR N. C. 1991. The Southern Western Ghats; A Biodiversity Plan Studied in Ecology and Sustainable Development, vol 4. Indian National Trust for Art \& Cultural Heritage INTACH, New Delhi.

Nair N. C. \& Henry A. N. 1983. Flora of Tamil Nadu, India. Series 1: Analysis vol 1, Botanical Survey of India, Coimbatore.

NAYAR M. P. 1977. Changing pattern of distribution of endemic genera (Angiosperm). Journal of Economic and Taxonomic Botany 1: 99-110.

NAYAR M. P. 1980a. Endemism and patterns of distribution of endemic genera (Angiosperms) in India. J. Eco. Tax. Bot. Vol. 1: 99-110.

NAYAR M. P. 1980b. Endemic flora of Peninsular India and its significance. Bull. Bot. Surv. India 22(1-4): 12-23.

NAYAR M. P. 1996. "Hot Spots" of endemic plants of India, Nepal and Bhutan. Tropical Botanic Garden and Research Institute. Palode, Thiruvananthapuram.

Nayar M. P., Ahmed M. \& Raju D. C. S. 1984. Endemic and Rare Plants of Eastern Ghats. Indian J. Forestry 7(1): 35-42.

Pannell C. M. 1998. Aglaia elaeagnoidea. The IUCN Red List of Threatened Species 1998: e.T33711A9804005. http://dx.doi.org/10.2305/IUCN.UK.1998.RLTS. T33711A9804005.en. Downloaded on 28 June 2017. 
Parthasarathy N., Selwyn M. A. \& Udayakumar M. 2008. Tropical dry evergreen forests of Peninsular India: Ecology and conservation significance. Trop Conserv Sci 1(2): 89-110. Doi.org/10.1177/ 194008290800100203

Pitman N. C. A. \& Jørgensen P. M. 2002. Estimating the size of the Worlds Threatened Flora. Science 298: 989. Doi: 10.1126/science.298.5595.989

Prabhu Kumar K. M., Binu T., Sreeraj V., Indira B. \& RaJENDRAN A. 2013. Critical notes on the occurrence of Dipcadi montanum (Dalz.) Baker (Hyacinthaceae) in South India. Science Research Reporter 3(2): 120-123.

Praveen Kumar C. K. 2011. Plant Biodiversity and Biocultural Perspectives of Ten Sacred Groves in Cuddalore districts on Tamil Nadu, South India. Ph.D Thesis, Pondicherry University.

Ramachandran V. S., Balasubramaniam V. \& Pandikumar P. 2006. Additions to the grass flora of Tamil Nadu. Journal of Bombay Natural History Society 102(3): 362-365.

Ramanujam M. P., Ganesan T., Kadamban D., Kumaravelu G. \& Devaraj P. 2007. Flora of Sacred Groves of Puducherry (A Pictorial Guide). 186 pp. Forest Department, Puducherry.

Ramanujam M. P. \& Kadamban D. 1999. Rare, endangered and threatened plants occurring in the sacred groves of Pondicherry bioregion. In: National symposium on Emerging Trends in Plant Sciences. Dept. of Botany, Sri Venkateswara University, Tirupati, Abstract 5, p. 43.

Rao B. R. P., Babu M. V. S., Reddy A.M., Sunitha S., Narayanaswamy A., Lakshminarayana G. \& Ahmedullah M. 2011. Conservation status of Hildegardia populifolia (Roxb.) Schott \& Endl. (Malvaceae: Stervulioideae: Sterculieae), an endemic of southern peninsular India. Journal of Threatened Taxa 3(8): 2018-2022.

ReHel S. 2011. Lindernia minima. The IUCN Red List of Threatened Species 2011: e.T177197A7387587. http://dx.doi.org/10.2305/IUCN.UK.2011-1.RLTS. T177197A7387587.en. Downloaded on 28 June 2017.

Singh P., Karthigeyan K., Lakshminarasimhan P. \& Dash S. S. 2015. Endemic Vascular Plants of India. i-ixvi, 1-339 pp. Botanical Survey of India, Kolkata.
Singh P. \& DASh S. S. 2014. Plant Discoveries 2013. Botanical Survey of India, Kolkata.

Sudhakar Reddy C. \& Raju V. S. 2008. Endemic Spermatophytes of Andhra Pradesh, India. Proc. A. P. Akademi of Sciences 12. 48-75.

The Plant List (2010). Version 1. Published on the Internet; http://www.theplantlist.org/ (Accessed on 8 May 2017).

Tнотнатнri K. 1982. Fascicles of Flora of India 8. Derris. Calcutta: Botanical Survey of India, Calcutta.

Uma Maheshwari P. \& Daniel P. 2001. Flora of Gulf of Mannar. 688 pp. Botanical Survey of India, Kolkata.

UNEP 1995. Global Biodiversity Assessment. Cambridge University Press, Cambridge.

Ved D., Saha D., Ravikumar K. \& Haridasan K. 2015. Decalepis hamiltonii. The IUCN Red List of Threatened Species 2015: e.T50126587A50131330. http: //dx.doi.org/10.2305/IUCN.UK.2015-2.RLTS. T50126587A50131330.en. Downloaded on 28 June 2017.

Venkateswaran R. \& Parthasarthy N. 2003. Tropical dry evergreen forests on the Coromandel Coast of India: Structure, composition and human disturbance. Ecotropica 9: 45-58.

Viswanathan M. B. \& Manikandan U. 2008. A new species of Hedyotis (Rubiaceae) from India. Edinburgh Journal of Botany 65(3): 387-392.

Walter K. S. \& Gillett H. J. (eds.). 1998 (1997). IUCN Red List of Threatened Plants. Compi. World Conservation Monitoring Centre. IUCN - The World Conservation Union, Gland.

WCMC 1998. World Conservation Monitoring Centre. Drypetes porteri (e.T38763A10143318); Hildegardia populifolia (e.T33656A9801072). The IUCN Red List of Threatened Species. http://dx.doi.org/10.2305/IUCN. UK.1998.RLTS. T38763A10143318.en. Downloaded on 28 June 2017.

Yarrayya K., Murthy G. V. S. \& Ratna Kumar P. K. 2015. Addition of Sedges to the flora of Tamil Nadu state. Ind J Plant Sci 4(4): 57-59. 
Appendix 1. Endemic plants of the Coromandel Coast of north Tamil Nadu with their distribution and threat status, including two doubtful endemic taxa $(*)$

\begin{tabular}{|c|c|c|c|c|c|}
\hline No. & Species name & Family name & $\begin{array}{l}\text { Growth } \\
\text { form }\end{array}$ & Distribution & $\begin{array}{l}\text { Threat } \\
\text { status }\end{array}$ \\
\hline 1 & Acalypha alnifolia Klein ex Willd. & Euphorbiaceae & $\mathrm{H}$ & SI & $\mathrm{NE}$ \\
\hline 2 & Acalypha malabarica Müll. Arg. & Euphorbiaceae & $\mathrm{H}$ & PI & $\mathrm{NE}$ \\
\hline 3 & Aglaia elaeagnoidea (A. Juss.) Benth. & Meliaceae & $\mathrm{T}$ & SI & NT \\
\hline 4 & Andrographis affinis Nees & Acanthaceae & $\mathrm{H}$ & SI & $\mathrm{NE}$ \\
\hline 5 & Andrographis serpyllifolia (Vahl) Wight & Acanthaceae & $\mathrm{H}$ & SI & $\mathrm{NE}$ \\
\hline 6 & Apocopsis courtallumensis (Steud.) Henrard & Poaceae & $\mathrm{H}$ & PI & $\mathrm{NE}$ \\
\hline 7 & Argyreia kleiniana Raizada & Convolvulaceae & $\mathrm{C}$ & PI & $\mathrm{NE}$ \\
\hline 8 & Barleria cuspidata F. Heyne ex Nees & Acanthaceae & $\mathrm{H}$ & PI & $\mathrm{NE}$ \\
\hline 9 & Barleria longiflora L.f. & Acanthaceae & $\mathrm{H}$ & PI & $\mathrm{NE}$ \\
\hline 10 & Barleria montana Nees & Acanthaceae & $\mathrm{H}$ & PI & $\mathrm{NE}$ \\
\hline 11 & Blumea eriantha DC. & Asteraceae & $\mathrm{H}$ & SI & $\mathrm{NE}$ \\
\hline 12 & Cadaba trifoliata Wight \& Arn. & Capparaceae & $\mathrm{S}$ & SI & $\mathrm{NE}$ \\
\hline 13 & Caralluma indica (Wight \& Arn.) N. E. Br. & Apocynaceae & $\mathrm{H}$ & SI & $\mathrm{NE}$ \\
\hline 14 & Carissa salicina Lam. & Apocynaceae & $\mathrm{S}$ & Tamil Nadu & $\mathrm{NE}$ \\
\hline 15 & Chlorophytum malabaricum Baker & Asparagaceae & $\mathrm{H}$ & PI & $\mathrm{NE}$ \\
\hline 16 & Chrysopogon verticillatus (Roxb.) Trin. ex Steud. & Poaceae & $\mathrm{H}$ & PI & NT \\
\hline 17 & Cleome felina L.f. & Cleomaceae & $\mathrm{H}$ & PI & $\mathrm{NE}$ \\
\hline 18 & Cordia ramanujamii N. Balach. \& K. Rajendiran & Cordiaceae & $\mathrm{T}$ & Tamil Nadu & $\mathrm{NE}$ \\
\hline 19 & Crotalaria pulchra Andrews & Leguminosae & S & SI & $\mathrm{NE}$ \\
\hline 20 & Crotalaria pusilla DC. & Leguminosae & $\mathrm{H}$ & India & $\mathrm{NE}$ \\
\hline 21 & Crotalaria willdenowiana DC. & Leguminosae & $\mathrm{H}$ & EG \& WG & NT \\
\hline 22 & Cryptolepis grandiflora Wight & Apocynaceae & $\mathrm{C}$ & $\begin{array}{l}\text { SI \& AN } \\
\text { Islands }\end{array}$ & $\mathrm{NE}$ \\
\hline 23 & Cyanotis arcotensis $\mathrm{R} . \mathrm{S} . \mathrm{Rao}$ & Commelinaceae & $\mathrm{H}$ & PI & $\mathrm{NE}$ \\
\hline 24 & $\begin{array}{l}\text { Cyanotis papilionacea (Burm.f.) Schult. \& } \\
\text { Schult.f. }\end{array}$ & Commelinaceae & $\mathrm{H}$ & $\begin{array}{l}\text { Maharashtra, } \\
\text { Tamil Nadu }\end{array}$ & $\mathrm{NE}$ \\
\hline 25 & Cyanotis tuberosa (Roxb.) Schult. \& Schult.f. & Commelinaceae & $\mathrm{H}$ & PI & $\mathrm{NE}$ \\
\hline 26 & Decalepis hamiltonii Wight \& Arn. & Apocynaceae & $\mathrm{C}$ & SI & EN \\
\hline 27 & $\begin{array}{l}\text { Deccania pubescens (Roth) Tirveng. var. } \\
\text { candolleana (Wight \& Arn.) Tirveng. }\end{array}$ & Rubiaceae & $\mathrm{T}$ & EG & $\mathrm{NE}$ \\
\hline 28 & Derris ovalifolia (Wight et Arn.) Benth. & Leguminosae & $\mathrm{C}$ & Tamil Nadu & NT \\
\hline 29 & Dicliptera cuneata Nees & Acanthaceae & $\mathrm{H}$ & SI & $\mathrm{NE}$ \\
\hline 30 & $\begin{array}{l}\text { Dipcadi montanum (Dalzell) Baker var. } \\
\text { madrasicum (E. Barnes \& C. E. C. Fisch.) Deb \& } \\
\text { S. Dasgupta }\end{array}$ & Asparagaceae & $\mathrm{H}$ & Tamil Nadu & NT \\
\hline 31 & Discospermum sphaerocarpum Dalzell ex Hook.f. & Rubiaceae & $\mathrm{T}$ & $\begin{array}{l}\text { Maharashtra, } \\
\text { Tamil Nadu }\end{array}$ & NT \\
\hline 32 & Dolichandrone atrovirens (Roth) K. Schum. & Bignoniaceae & $\mathrm{T}$ & SI & $\mathrm{NE}$ \\
\hline 33 & Dolichandrone falcata (Wall. ex DC.) Seem. & Bignoniaceae & $\mathrm{T}$ & India & $\mathrm{NE}$ \\
\hline 34 & Drypetes porteri (Gamble) Pax \& K.Hoffm. & Putranjivaceae & $\mathrm{T}$ & Tamil Nadu & EN \\
\hline 35 & Emilia scabra DC. & Asteraceae & $\mathrm{H}$ & SI & $\mathrm{NE}$ \\
\hline 36 & Euphorbia corrigioloides Boiss. & Euphorbiaceae & $\mathrm{H}$ & PI & $\mathrm{NE}$ \\
\hline 37 & Euphorbia elegans Spreng. & Euphorbiaceae & $\mathrm{H}$ & PI & $\mathrm{NE}$ \\
\hline 38 & Fimbristylis woodrowii C. B. Clarke & Cyperaceae & $\mathrm{H}$ & SI & $\mathrm{NE}$ \\
\hline 39 & Garnotia elata (Arn. ex Miq.) Janowski & Poaceae & $\mathrm{H}$ & $\begin{array}{l}\text { SI \& Uttar } \\
\text { Pradesh }\end{array}$ & $\mathrm{NE}$ \\
\hline 40 & Glossocardia bosvallia (L.f.) DC. & Asteraceae & $\mathrm{H}$ & $\begin{array}{l}\text { SI \& Uttar } \\
\text { Pradesh }\end{array}$ & $\mathrm{NE}$ \\
\hline 41 & Habenaria roxburghii Nicolson & Orchidaceae & $\mathrm{H}$ & PI & $\mathrm{NE}$ \\
\hline 42 & Hardwickia binata Roxb. & Leguminosae & $\mathrm{T}$ & India & $\mathrm{NE}$ \\
\hline 43 & $\begin{array}{l}\text { Heterophragma quadriloculare (Roxb.) K. } \\
\text { Schum. }\end{array}$ & Bignoniaceae & $\mathrm{T}$ & PI & $\mathrm{NE}$ \\
\hline 44 & $\begin{array}{l}\text { Huberantha senjiana (R. Muralidharan, Naras. \& } \\
\text { N. Balach.) R. Muralidharan, Naras. \& N. Balach. }\end{array}$ & Annonaceae & S & Tamil Nadu & $\mathrm{NE}$ \\
\hline 45 & Indigofera mysorensis DC. & Leguminosae & $\mathrm{H}$ & $\begin{array}{l}\text { SI \& West } \\
\text { Bengal }\end{array}$ & $\mathrm{NE}$ \\
\hline
\end{tabular}




\begin{tabular}{|c|c|c|c|c|c|}
\hline No. & Species name & Family name & $\begin{array}{l}\text { Growth } \\
\text { form }\end{array}$ & Distribution & $\begin{array}{l}\text { Threat } \\
\text { status }\end{array}$ \\
\hline 46 & Indigofera prostrata Willd. & Leguminosae & $\mathrm{H}$ & PI & $\mathrm{NE}$ \\
\hline 47 & Iseilema anthephoroides Hack. & Poaceae & $\mathrm{H}$ & PI \& Gujarat & NE \\
\hline 48 & Jatropha heynei N. P. Balakr. & Euphorbiaceae & $\mathrm{H}$ & PI & NE \\
\hline 49 & Jatropha tanjorensis J. L. Ellis \& Saroja & Euphorbiaceae & $\mathrm{S}$ & PI & NE \\
\hline 50 & Justicia beddomei (C. B. Clarke) Bennet & Acanthaceae & S & SI & NT \\
\hline 51 & Justicia glauca Rottler & Acanthaceae & $\mathrm{H}$ & PI & NE \\
\hline 52 & Justicia neesii Ramamoorthy & Acanthaceae & $\mathrm{H}$ & SI & NE \\
\hline 53 & Leucas diffusa Benth. & Lamiaceae & $\mathrm{H}$ & SI \& Delhi & NE \\
\hline 54 & Leucas wightiana Wall. ex Benth. & Lamiaceae & $\mathrm{H}$ & SI \& Gujarat & NT \\
\hline 55 & Lindernia minima (Benth.) Mukerjee & Linderniaceae & $\mathrm{H}$ & Tamil Nadu & EN \\
\hline 56 & Lophopogon tridentatus (Roxb.) Hack. & Poaceae & $\mathrm{H}$ & PI \& Gujarat & NE \\
\hline 57 & Mallotus resinosus (Blanco) Merr. & Euphorbiaceae & $\mathrm{T}$ & WG \& EG & NE \\
\hline 58 & Manilkara roxburghiana (Wight) Dubard & Sapotaceae & $\mathrm{T}$ & SI & NE \\
\hline 59 & Manisuris myurus L. & Poaceae & $\mathrm{H}$ & SI \& Manipur & NE \\
\hline 60 & Melothria angulata Chakrav. & Cucurbitaceae & $\mathrm{C}$ & SI & NT \\
\hline 61 & Miliusa eriocarpa Dunn & Annonaceae & $\mathrm{S}$ & SI & NE \\
\hline 62 & Mussaenda glabrata (Hook.f.) Hutch. ex Gamble & Rubiaceae & S & WG \& EG & NE \\
\hline 63 & Mussaenda tomentosa Wall. ex G. Don & Rubiaceae & $\mathrm{S}$ & Tamil Nadu & NE \\
\hline 64 & Oldenlandia attenuata (Willd.) M. R. Almeida & Rubiaceae & $\mathrm{H}$ & $\begin{array}{l}\text { EG \& Uttar } \\
\text { Pradesh }\end{array}$ & NE \\
\hline 65 & Phyllanthus indofischeri Bennet & Phyllanthaceae & $\mathrm{T}$ & SI & $\mathrm{NE}$ \\
\hline 66 & Polycarpaea aurea Wight \& Arn. & Caryophyllaceae & $\mathrm{H}$ & PI & NE \\
\hline 67 & $\begin{array}{l}\text { Polycarpaea corymbosa (L.) Lam. var. } \\
\text { longipetala S. R. Sriniv. \& D. Naras. }\end{array}$ & Caryophyllaceae & $\mathrm{H}$ & EG \& WG & $\mathrm{NE}$ \\
\hline 68 & Psilotrichum nudum Wight & Amaranthaceae & $\mathrm{H}$ & SI & $\mathrm{NE}$ \\
\hline 69 & Pterocarpus santalinus L.f. & Leguminosae & $\mathrm{T}$ & EG & EN \\
\hline 70 & $\begin{array}{l}\text { Pterospermum xylocarpum (Gaertn.) Santapau \& } \\
\text { Wagh }\end{array}$ & Malvaceae & $\mathrm{T}$ & PI & $\mathrm{NE}$ \\
\hline 71 & Rhynchosia courtallensis Maesen & Leguminosae & $\mathrm{C}$ & SI & NT \\
\hline 72 & Sarcostemma intermedium Decne. & Apocynaceae & $\mathrm{C}$ & PI & NE \\
\hline 73 & Scleria stocksiana Boeckeler & Cyperaceae & $\mathrm{H}$ & India & NE \\
\hline 74 & Senna montana (Roth) V. Singh & Leguminosae & S & SI \& Gujarat & NE \\
\hline 75 & Solena amplexicaulis (Lam.) Gandhi & Cucurbitaceae & $\mathrm{C}$ & SI & NE \\
\hline 76 & Sterculia populifolia DC. & Malvaceae & $\mathrm{T}$ & EG & $\mathrm{CR}$ \\
\hline 77 & Taxillus heyneanus Danser & Loranthaceae & $\mathrm{S}$ & SI & NE \\
\hline 78 & Terminalia paniculata Roth & Combretaceae & $\mathrm{T}$ & PI & NE \\
\hline 79 & Tetrastigma tamilnadense N. Balach. \& K. Ravik. & Vitaceae & $\mathrm{C}$ & Tamil Nadu & NE \\
\hline 80 & $\begin{array}{l}\text { Tribulus subramanyamii P. Singh, G. S. Giri \& V. } \\
\text { Singh }\end{array}$ & Zygophyllaceae & $\mathrm{H}$ & PI & $\mathrm{NE}$ \\
\hline 81 & Tricholepis radicans (Roxb.) DC. & Asteraceae & $\mathrm{H}$ & $\begin{array}{c}\text { SI \& } \\
\text { Rajasthan }\end{array}$ & $\mathrm{NE}$ \\
\hline 82 & $\begin{array}{l}\text { Vitex negundo L. var. purpurascens Sivar. \& } \\
\text { Moldenke }\end{array}$ & Lamiaceae & $\mathrm{T}$ & SI & NE \\
\hline 83 & Sehima sulcatum (Hack.) A.Camus* & Poaceae & $\mathrm{H}$ & India & NE \\
\hline 84 & Zenkeria elegans Trin.* & Poaceae & $\mathrm{H}$ & SI & EN \\
\hline
\end{tabular}

Explanations: H - Herb, S - Shrub, T - Tree, C - Climber; SI - Southern India, PI - Peninsular India, EG - Eastern Ghats, WG - Western Ghats, AN - Andaman \& Nicobar Islands; NE - Not Evaluated; NT - Near Threatened; EN - Endangered; CR - Critically Endangered 
Appendix 2. Endemic plants from the Coromandel Coast of north Tamil Nadu endemic to: a - Tamil Nadu, b - Eastern Ghats, c - Eastern Ghats \& Western Ghats

a

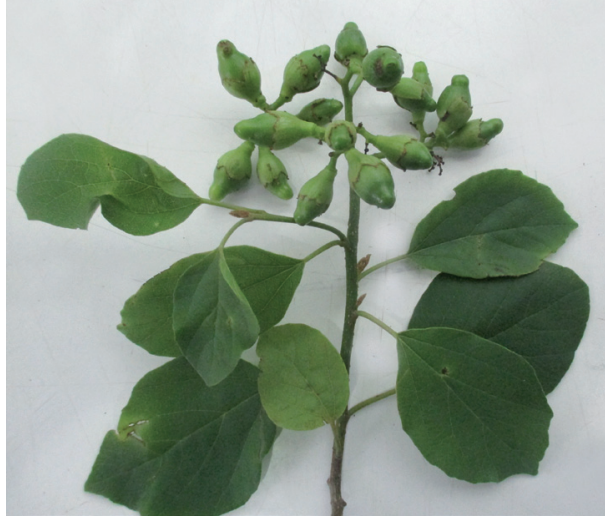

Cordia ramanujamii

b

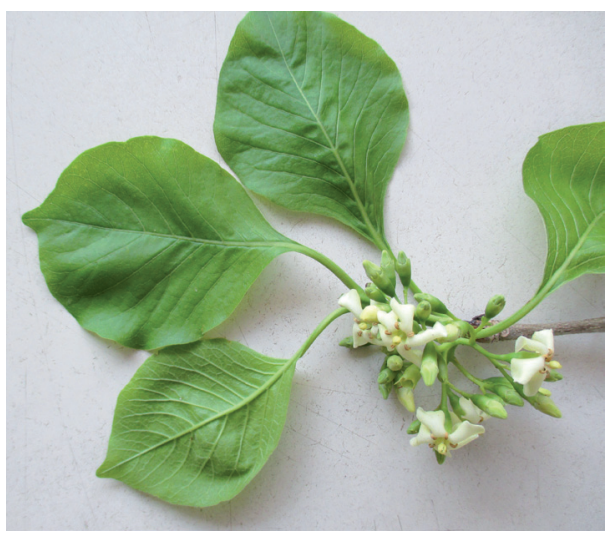

Deccania pubescens

$\mathrm{c}$

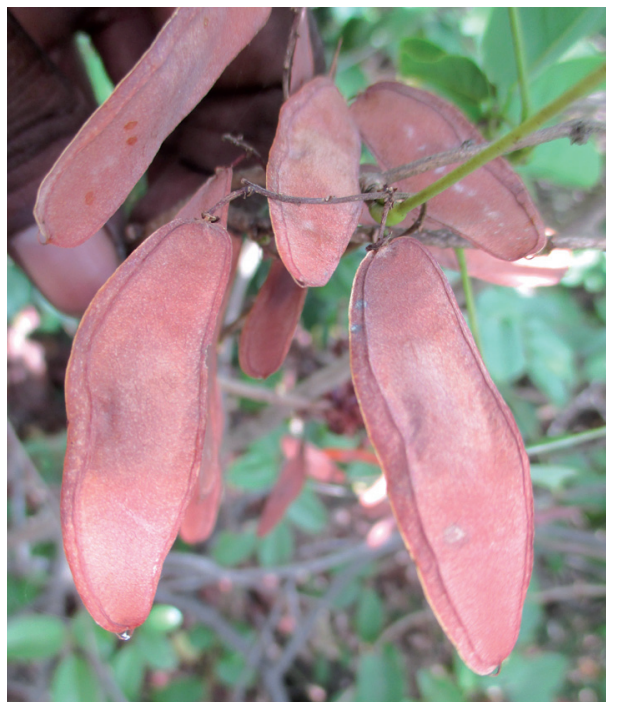

Derris ovalifolia

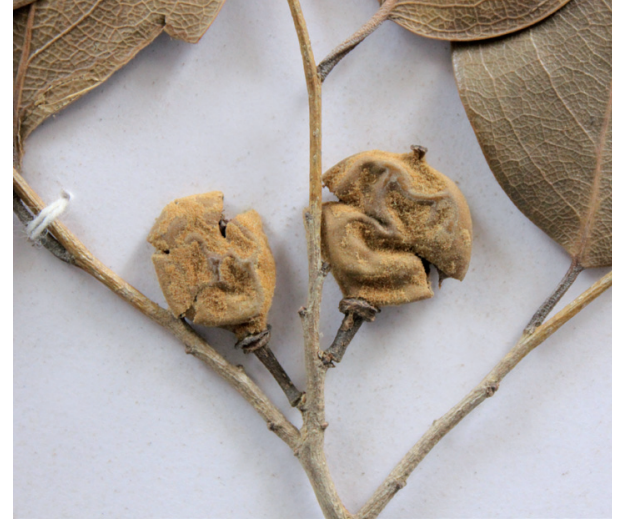

Drypetes porteri

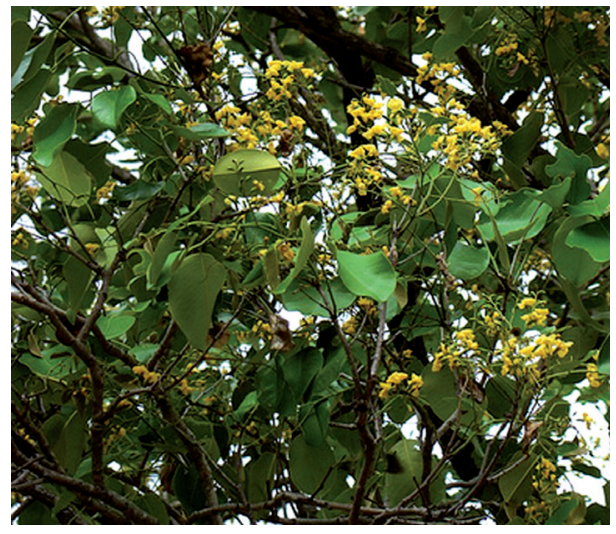

Pterocarpus santalinus

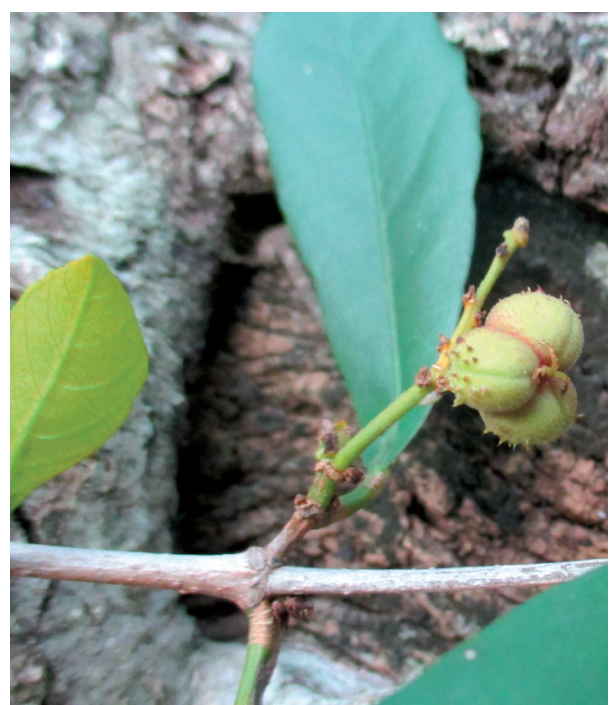

Mallotus resinosus var. muricatus

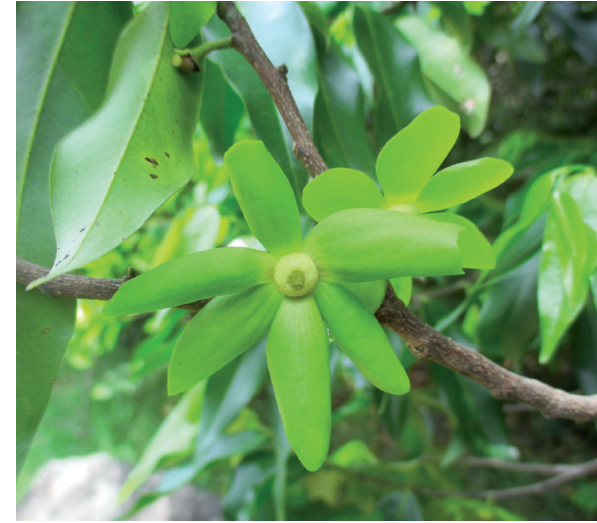

Huberantha senjiana

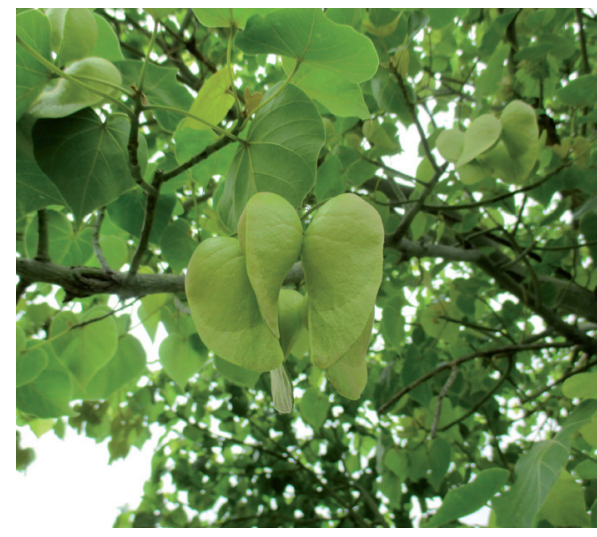

Sterculia polpulifolia

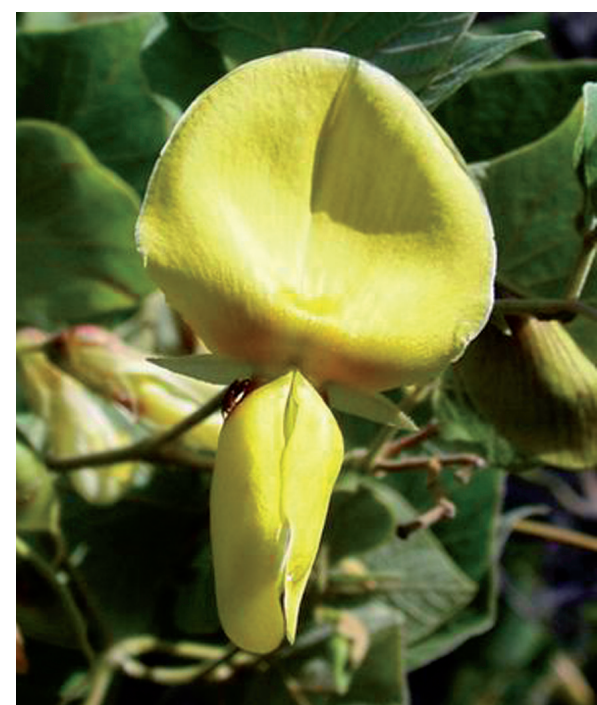

Rhynchosia courtallensis 
Appendix 3. Endemic plants from the Coromandel Coast of north Tamil Nadu endemic to: a - Southern India, $\mathrm{b}$ - Peninsular India, c - Entire India

a

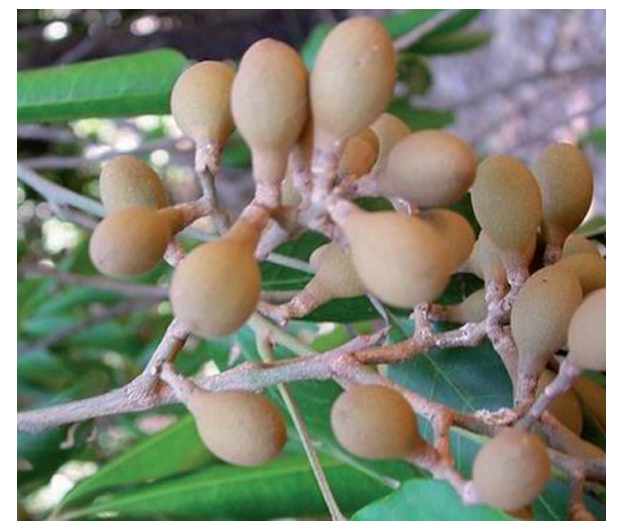

Aglaia elaeagnoidea

b

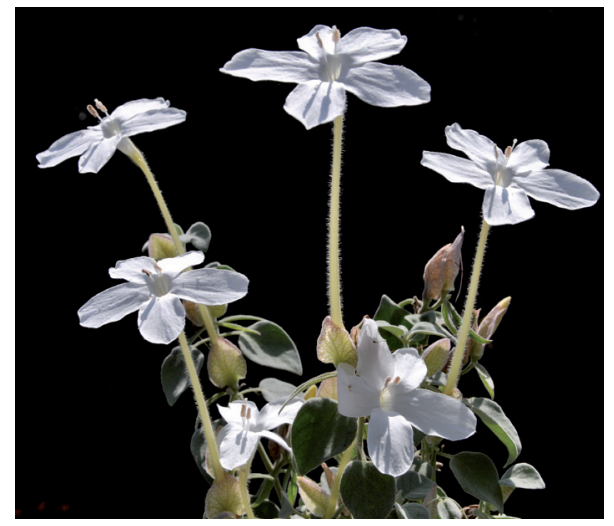

Barleria longiflora

$\mathrm{c}$

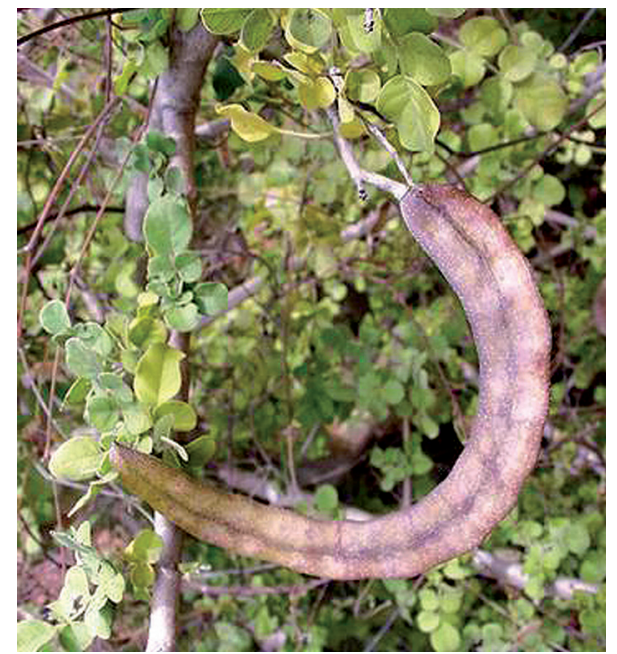

Dolichandrone falcata

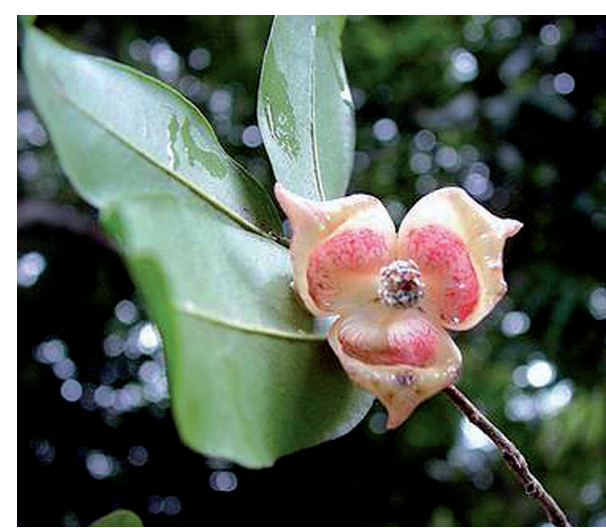

Miliusa eriocarpa

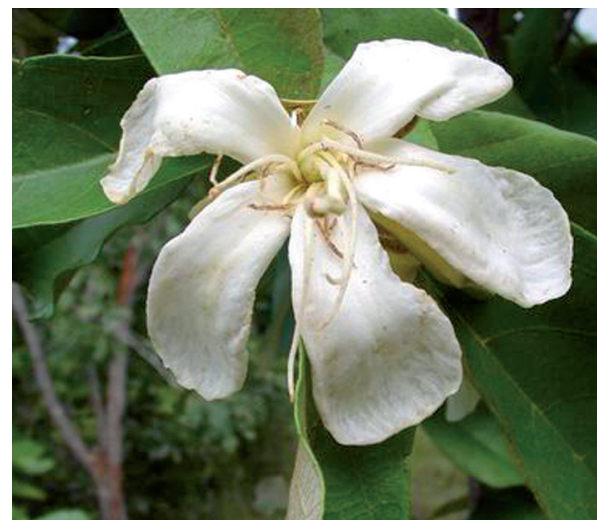

Pterospermum xylocarpum

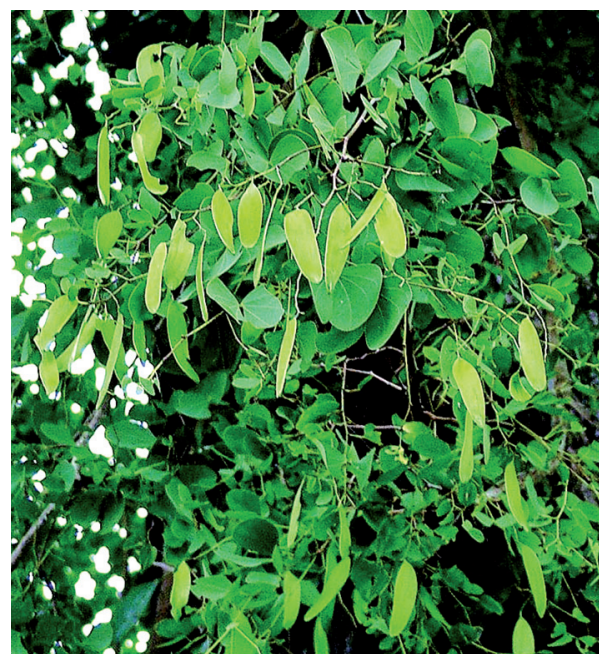

Hardwickia binata

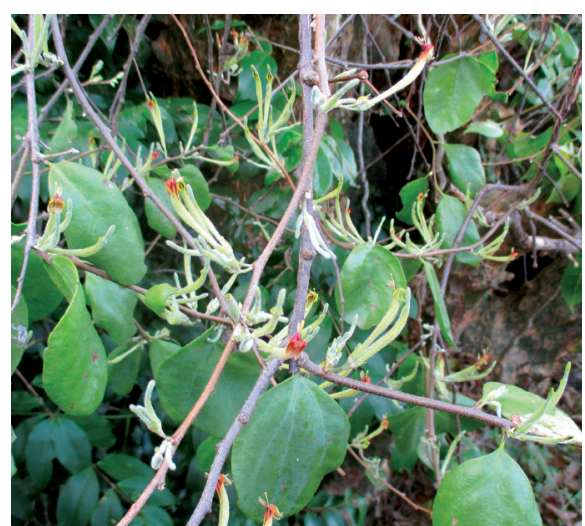

Taxillus heyneanus

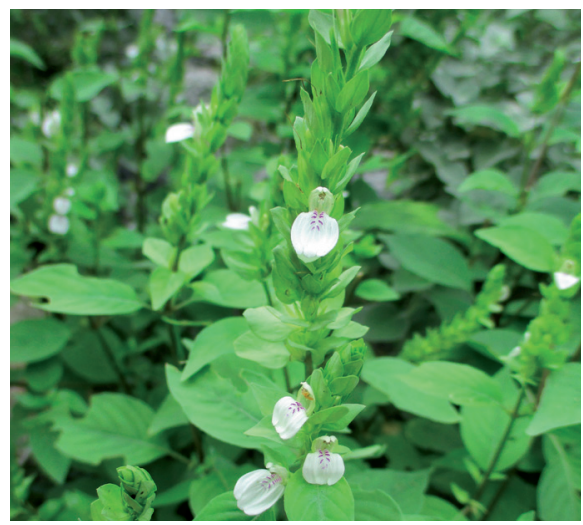

Justicia glauca

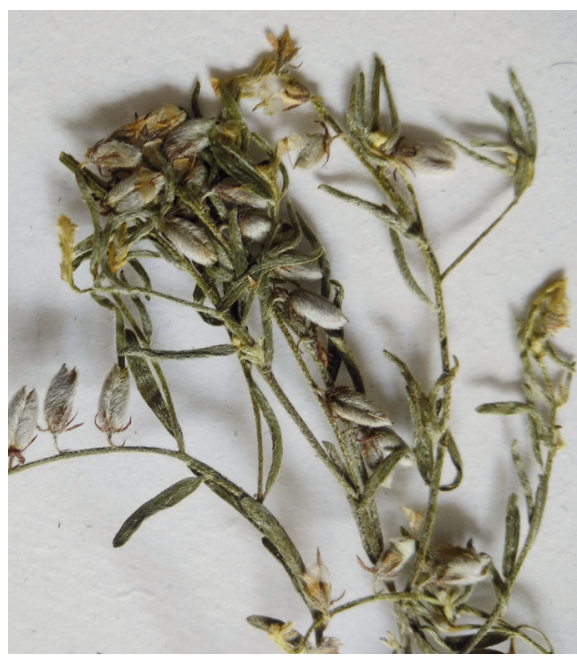

Crotalaria pusilla 
Appendix 4. Disjunctly distributed endemic plants from the Coromandel Coast of north Tamil Nadu: $\mathrm{a}$ - within the state Tamil Nadu, b - within the state Tamil Nadu and Peninsular India, $\mathrm{c}-$ between two bioregions

a

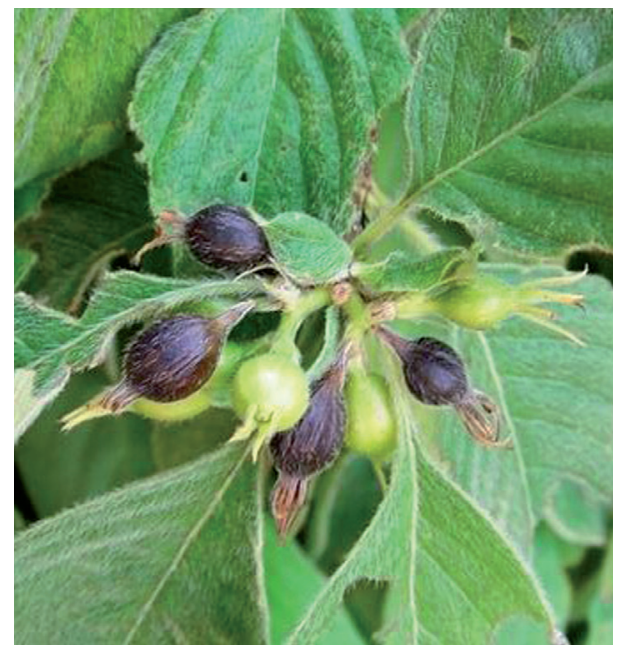

b

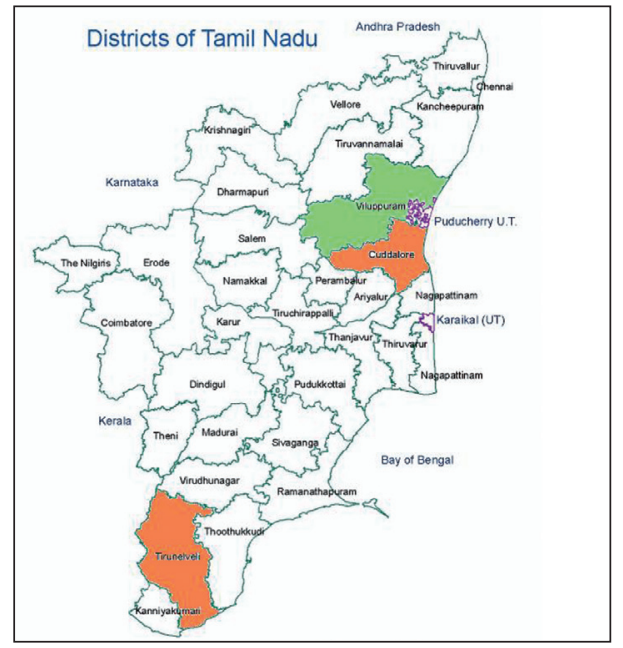

$\mathrm{c}$

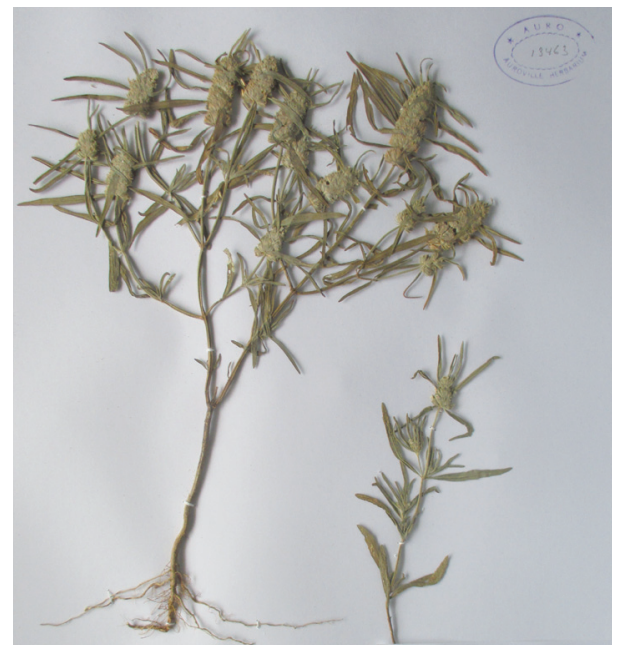

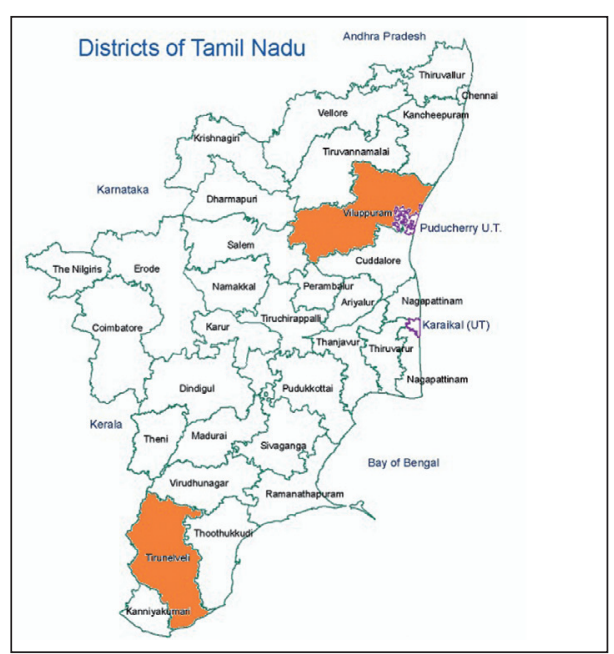

Mussaenda tomentosa \& Justicia beddomei

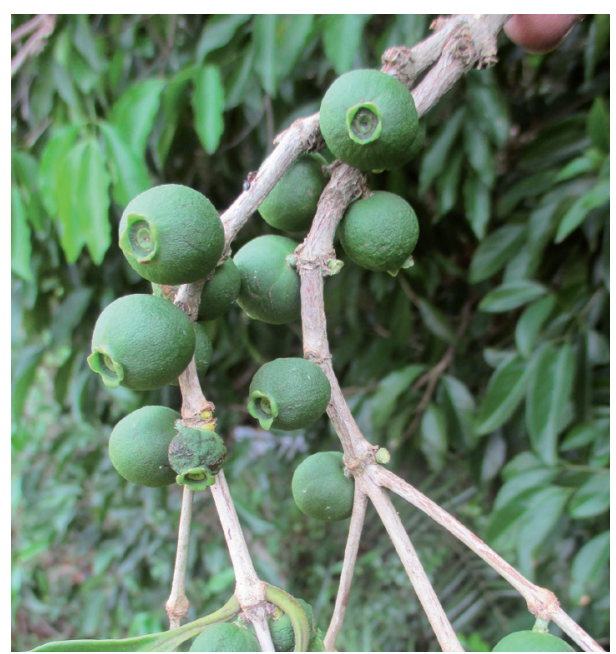

Discospermum sphaerocarpum
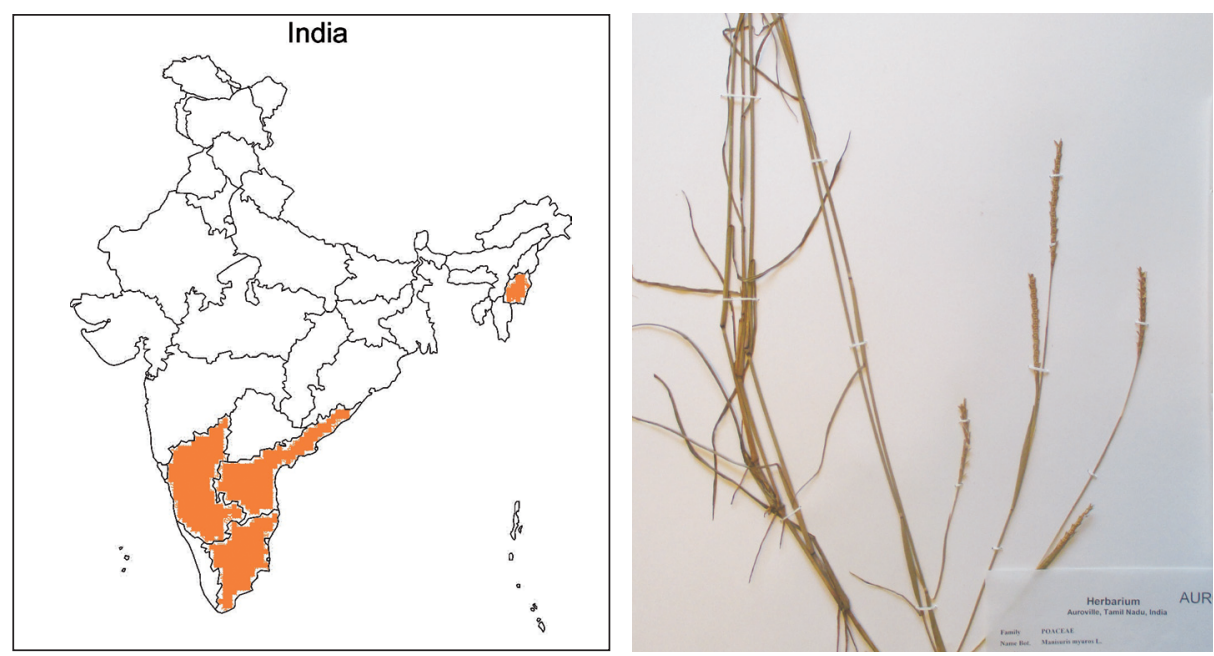
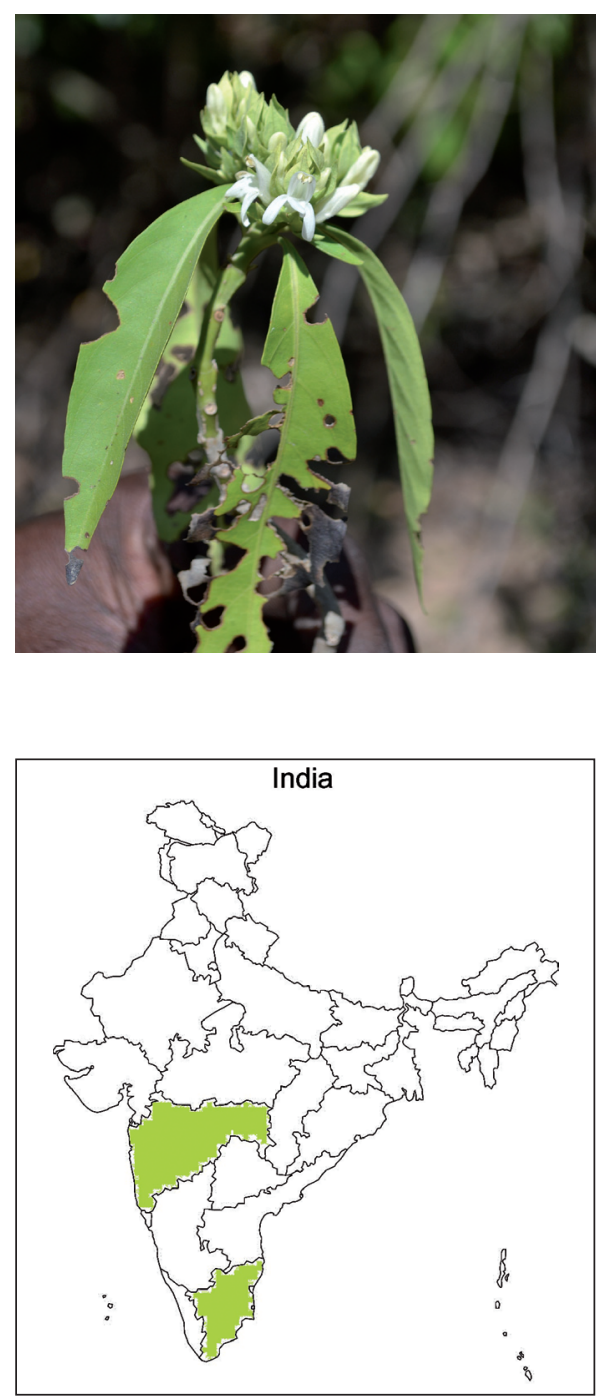

;

Leucas wightiana \& Manisuris myurus 